\section{A word of thanks}

Serving as the ACRL BI Liaison Project program officer has been a rewarding yet frustrating experience. There seems to be much potential in continuing professional liaisons on an ongoing and intensive basis to form cooperative friendships. Communicating activities of the project through this column has proved to be the best way for librarians to learn about potentials for involvement, and your response to requests for information and volunteers is much appreciated. There has not been time to communicate personally with all the individual contact names that our project has collected, but as the liaison emphasis grows a followup can be made.

It seems that the most direct route for librarians to participate on the programs of other professional associations in higher education is the logical one of starting at the local, state, and regional levels. Librarians who have taken membership in these associations, who have volunteered to serve on com- mittees relating to teaching and research, who suggest ideas for joint panels and presentations, and who work on their local campuses with teaching faculty to promote the academic library's role in assisting the teaching/learning process, are providing the kinds of liaisons necessary for success with this kind of project. It has been much more difficult to try to place librarians as speakers on the national level at other organizations' conferences. Probably the most visible means toward having teaching faculty develop an awareness of the library's potential is for them to read about our programs in the professional literature of higher education. Therefore, our project continues to encourage librarians to prepare articles for publication outside the library field.

Many opportunities exist for those librarians who realize that talking to each other about vital library services is not enough. Thanks to the contributions and support from so many of you involved in our BI Liaison Project, promotion of our mission has been firmly established.

\title{
ACRL seeks volunteers for offices and
}

\section{committees}

\section{The Association needs your help to achieve its goals and objectives.}

W ould you like to run for an ACRL office or volunteer for appointment to an ACRL standing committee? Are you interested in seeking office in an ACRL section or being considered for appointment to a section committee? If the answer is yes to any of these questions, here is what you need to do.

\section{ACRL President}

The ACRL Appointments and Nominations Committee will nominate candidates for the office of ACRL vice-president/president-elect at the Jan- uary 1985 Midwinter Meeting of ALA. The election for this office will be held in the spring of 1986 . The winner of the election will serve as vicepresident/president-elect during 1986-87 and as president of ACRL during 1987-88. If you wish to be considered for nomination to this office or if you would like to submit names for consideration, contact the chair of the Appointments and Nominations Committee, Linda Piele, Head, Public Services Division, Library/Learning Center, University of Wisconsin-Parkside, Box 2000, Kenosha, WI 53141. 


\section{ACRL COMMITTEE VOLUNTEER FORM}

If you are interested in serving on an ACRL standing committee, please complete this form and mail it before December 15, 1984, to: Linda Piele, Head, Public Services Division, Library/Learning Center, University of Wisconsin-Parkside, Box 2000, Kenosha, WI 53141.

If you would like to serve on an ACRL section committee, send this form to the appropriate section vicechair/chair-elect before the ALA Midwinter Meeting.

NAME, TITLE, INSTITUTIONAL ADDRESS

PREFERRED MAILING ADDRESS

DATE OF APPLICATION

NUMBER OF YEARS AS MEMBER OF ALA ACRL

ACADEMIC BACKGROUND (List institutions, dates of degrees, and relevant subject areas)

PROFESSIONAL ACTIVITIES

ALA or ACRL Committee Assignments

State and Regional Committee Assignments

ALA or ACRL Offices Held

State and Regional Offices Held

Publications

Other

ACRL COMMITTEE PREFERENCES

RELEVANT BACKGROUND OR EXPERIENCE FOR COMMITTEE ASSIGNMENT

Can you regularly attend the ALA Midwinter and Annual conferences? YES __ NO

(Members of ACRL committees are expected to attend all meetings. Failure to attend two in a row may constitute grounds for removal.)

PLEASE EXPRESS YOUR MAJOR CONCERNS FOR STRENGTHENING THE ASSOCIATION OF COLLEGE AND RESEARCH LIBRARIES: 


\section{ACRL committees}

ACRL has 20 standing committees to which appointments may be made:

- Academic or Research Librarian of the Year Award Committee;

-Academic Status Committee;

- Appointments and Nominations Committee;

- Audiovisual Committee;

- Budget and Finance Committee;

- Conference Program Planning Committee;

- Constitution and Bylaws Committee;

- Continuing Education Committee;

- Continuing Education Courses Advisory Committee;

- Copyright Committee;

- Doctoral Dissertation Fellowship Committee;

- Legislation Committee;

- Membership Committee;

- National Conference Committee;

- Planning Committee;

-Professional Association Liaison Committee;

- Publications Committee;

- Samuel Lazerow Fellowship Committee;

- Standards and Accreditation Committee;

- Supplemental Funds Committee.

To learn about the areas of responsibility covered by these committees, see the ALA Handbook of Organization 1984-85.

When selected vacancies occur on ACRL standing committees, the Appointments and Nominations Committee recommends to the presidentelect of ACRL the names of members who might fill the vacancies. The president-elect makes the final appointments. If you are interested in being considered for appointment to an ACRL committee, you should complete the ACRL Committee Volunteer Form that is included in this issue of $C \& R L$ News and mail it to Linda Piele, chair of the Appointments and Nominations Committee, before December 15, 1984.

\section{ACRL section officers}

ACRL has 13 sections (their names are listed later in this article). You will find a description of their areas of responsibility in the ALA Handbook of Organization.

The chair-elect of a section appoints the chair and members of all section committees when scheduled vacancies on these committees occur. If you would like to be considered for appointment as chair or member of a section committee, fill out the ACRL Committee Volunteer Form and mail it to the chair-elect of the appropriate section (see "People to contact" below) before December 15, 1984.

\section{Editorial boards}

ACRL has four editorial boards:

- the Choice Editorial Board;

- the College \& Research Libraries Editorial Board;
- the College \& Research Libraries News Editorial Board;

- the Publications in Librarianship Editorial Board.

When a vacancy occurs on an editorial board, the editor recommends the name of a person to fill the vacancy. The Publications Committee must approve the recommendation. The ACRL Board must give its approval, and finally the president of ACRL makes the appointment.

If you would like to be considered for appointment to an editorial board, contact the editor of the publication (see "People to contact" below).

Remember that at any given time there are only a limited number of vacancies on ACRL's committees, sections, and editorial boards. If at first you don't succeed in obtaining an appointment, try again. Make yourself known to committee chairs by sitting in on meetings, volunteering to help with committee projects, etc. If committee chairs see that you are interested in the work of their committees, they may recommend your name to the appropriate appointing body when a vacancy occurs.

\section{People to contact}

\section{Anthropology and Sociology Section}

Vice-Chair/Chair-Elect: Jean Shaw Adelman, Associate Professor, Library, John Jay College of Criminal Justice, 445 West 59 th St., New York, NY 10019.

\section{Art Section}

Vice-Chair/Chair-Elect: Darryl Dean Barrett, Art and Music Division, Minneapolis Public Library, 300 Nicollet Mall, Minneapolis, MN 55401.

\section{Asian and African Section}

Vice-Chair/Chair-Elect: Thomas H. Lee, Team Captain, East Asian Languages Cataloging Team, University of Wisconsin Memorial Library, 728 State St., Madison, WI 53706.

Nominating Committee: Chair, Margaret K. Wang, 2508 Cinder Rd., Wilmington, DE 19810.

\section{Bibliographic Instruction Section}

Vice-Chair/Chair-Elect: Mary Reichel, Head, Reference Department, Pullen Library, Georgia State University, 100 Decatur St., SE, Atlanta, GA 30303.

Nominating Committee: Chair, Donald J. Kenney, Head, General Reference Department, University Libraries, Virginia Polytechnic Institute and State University, Blacksburg, VA 24060; Mary Ellen Larson, Senior Assistant Librarian, General Reference Section, E110 Pattee Library, Pennsylvania State University, University Park, PA 16802; Ellen J. Meltzer, 722 Santa Barbara Rd., Berkeley, CA 94707. 


\section{College Libraries Section}

Vice-Chair/Chair-Elect: Jean Clarridge Pelletiere, Rockefeller College, SUNY-Albany, 135 Western Avenue, Albany, NY 12222.

Nominating Committee: Chair, Dorothy Cieslicki, Librarian, Skillman Library, Lafayette College, Easton, PA 18042; Dennis Ribbens, Director, Lawrence University Library, Appleton, WI 54911; Keith E. Washburn, Library Director, Schmidt Library, York College, York, PA 17405.

\section{Community and Junior College Libraries Section}

Vice-Chair/Chair-Elect: James F. McCoy, Director of Learning Resources, Hudson Valley Community College, 80 Vandenburgh Ave., Troy, NY 12180.

Nominating Committee: Chair, Barbara Collinsworth, Associate Dean of Learning Resources, Macomb Community College, 14500 Twelve Mile Rd., Warren, MI 48093; Billy C. Beal, Acquisitions Librarian, L.O. Todd Library, Meridian Junior College, 5500 Highway 19 North, Meridian, MS 39305; Glen R. Dallman, Director, Learning Resources, M.M. Bennett Library, St. Petersburg Junior College, 2465 Drew St., Clearwater, FL 33575.

\section{Education and Behavioral Sciences Section}

Vice-Chair/Chair-Elect: Adele S. Dendy, Head, Education Library, Education Building, Indiana
University, Bloomington, IN 47405.

Nominating Committee: Chair, Virginia Parr, 461 McAlpin, Cincinnati, OH 45220; Harriet O. Nelson, Head, General Reference, Mullen Library, Catholic University, Washington, DC 20064; Charles Thurston, Education Reference Librarian, John Peace Library, University of Texas at San Antonio, San Antonio, TX 78285.

\section{Law and Political Science Section}

Vice-Chair/Chair-Elect: Kathleen Gunning, Assistant Director for Public Services and Collection Development, University of Houston, Houston, TX 77004.

\section{Rare Books and Manuscripts Section}

Vice-Chair/Chair-Elect: Anna Lou S. Ashby, Associate Curator of Printed Books, Pierpont Morgan Library, 29 E. 36th St., New York, NY 10016.

\section{Science and Technology Section}

Vice-Chair/Chair-Elect: Eleanor R. Mathews, Reference Librarian, Iowa State University Library, Ames, IA 50011.

\section{Slavic and East European Section}

Vice-Chair/Chair-Elect: Wojciech Zalewski, Curator for Russian and East European Collections, Stanford University Libraries, Stanford, CA 94305.

\section{Midwest Library Service}

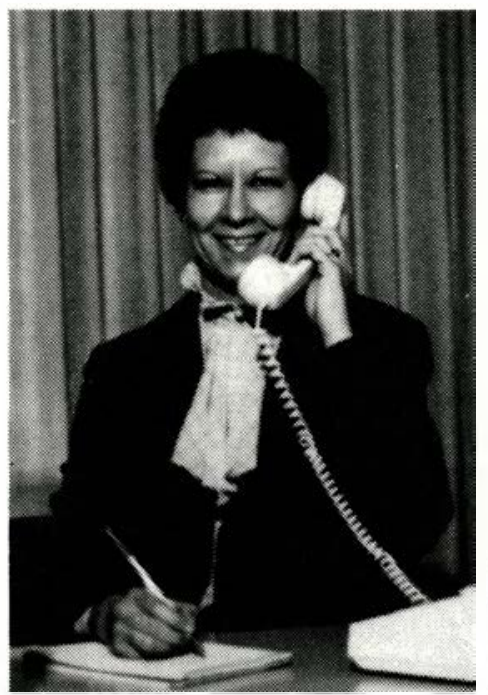

\section{You won't find more personal attention ... anywhere}

College and university librarians: We have what you're looking for. While Midwest utilizes state-of-the-art computer systems, we realize machines can't do it all So when you want to place an order, ask a question, or discuss a problem, you can call direct on Midwest's toll-free WATS line and conduct business on a name. to-name basis with your personal customer service representative. It's the kind of attention that Midwest has provided to college and university libraries for 24 years.

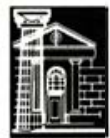

\section{Midwest Library Service \\ 11443 St. Charles Rock Road} Bridgeton, MO 63044

Call toll-free (800) $325-8833$

Missouri librarians call toll-free (800) 392-5024 Canadian librarians call collect (314) 739-3100 


\section{University Libraries Section}

Vice-Chair/Chair-Elect: Shelley E. Phipps, Head Librarian, Science-Engineering Library, University of Arizona, Tucson, AZ 85721.

Nominating Committee: Chair, Joan Chambers, University Librarian, 4045 Canyon Crest Drive, P.O. Box 5900, University of California, Riverside, CA 92507; Jordan Scepanski, Director, University Library and Learning Resources, 1250 Bellflower Rd., California State University, Long Beach, CA 90840; Jane Ross Moore, Graduate School and University Center, City University of New York, 33 West 42d St., New York, NY 10036.

\section{Western European Specialists Section}

Vice-Chair/Chair-Elect: James M. Campbell, North Europe Bibliographer, Alderman Library, University of Virginia, Charlottesville, VA 22901.

Nominating Committee: Chair, Mariann
Tiblin, 3332 18th Ave., Minneapolis, MN 55407; John B. Dillon, 3 River St., Binghamton, NY 13901; Eva Sartori, Assistant Professor, Humanities/Social Sciences, Love Library 201S, University of Nebraska, Lincoln, NE 68588-0410.

\section{Editorial Boards}

Choice Editor: Patricia Sabosik, Choice, 100 Riverview Center, Middletown, CT 06475.

College \& Research Libraries Editor: Charles Martell, Associate University Librarian for Public Services, California State University, Sacramento, 2000 Jed Smith Drive, Sacramento, CA 95819.

College \& Research Libraries News Editor: George M. Eberhart, ACRL/ALA, 50 E. Huron St., Chicago, IL 60611-2795.

ACRL Publications in Librarianship Editor: Arthur P. Young, Dean of Libraries, University of Rhode Island, Kingston, RI 02881.

\section{New York provides more aid for academic libraries}

New York's Governor Cuomo signed a major bill increasing aid to all types of libraries in the state on July 10, 1984. Under the bill, state aid for libraries will increase from $\$ 42.1$ million to $\$ 57.2$ million in fiscal year 1985 .

Among the important new initiatives authorized in this legislation are $\$ 1.3$ million in annual grants to assist in regional automation projects, and $\$ 1.1$ million in annual grants for preservation and conservation of research materials. Also included in the aid package is increased support for coordinated collection development programs in academic libraries, raising per capita allocation levels from $46 \mathrm{c}$ to $60 \mathrm{c}$ per student.

Eleven research libraries in the state are eligible for $\$ 45,000$ this fall and another $\$ 90,000$ in the spring for preservation activities that will be outlined in a 5-year plan to be submitted by each eligible institution to the state next winter. Recently enacted guidelines allow the annual grants to be used for a wide variety of activities for the protection, care and treatment of library materials to prevent the loss of their informational or intellectual content and/or of the objects themselves.

Such activities may include but not be limited to:

-collection condition evaluation and preservation planning;

- environmental control;

- disaster prevention, preparedness and recovery;

- preparation of library research materials for storage or exhibition, including binding, matting, boxing, and other protective wrapping;

- collection maintenance, including cleaning and refurbishing;

- screening to identify items needing preserva- tion attention, including searching to establish the availability of replacement;

- rebinding, minor repair and mending;

- reformatting, including photocopying, microfilming, and copying disks to tape;

- major conservation treatment, such as surface cleaning, deacidification, leather repair, and conservation rebinding;

- creating or modifying bibliographic records to reflect preservation decisions, including reporting microform masters to the library community;

- quality control and testing of materials, processes and equipment used in any conservation and or preservation activity; and

- Staff training and patron awareness programs.

Regional automation projects are expected to focus on retrospective conversion activities. Grants of up to $\$ 200,000$ per multi-type regional library resource sharing agency will support conversion, maintenance, updating and linking of bibliographic records to increase availability of materials for resource sharing. The program requires each region to establish a five-year plan for their automation programs.

No other state supports its libraries in general or its academic libraries in particular at a level comparable to New York. The passage of this legislation is indeed testimony of the state"s commitment to education and the New York Library Association's lobbying efforts. The bill was drafted by Assemblyman Ed Sullivan of Manhattan and Senator Hugh Farley of Schenectady. Sponsors included many other legislators and all members of both houses voted for the final compromise language. 


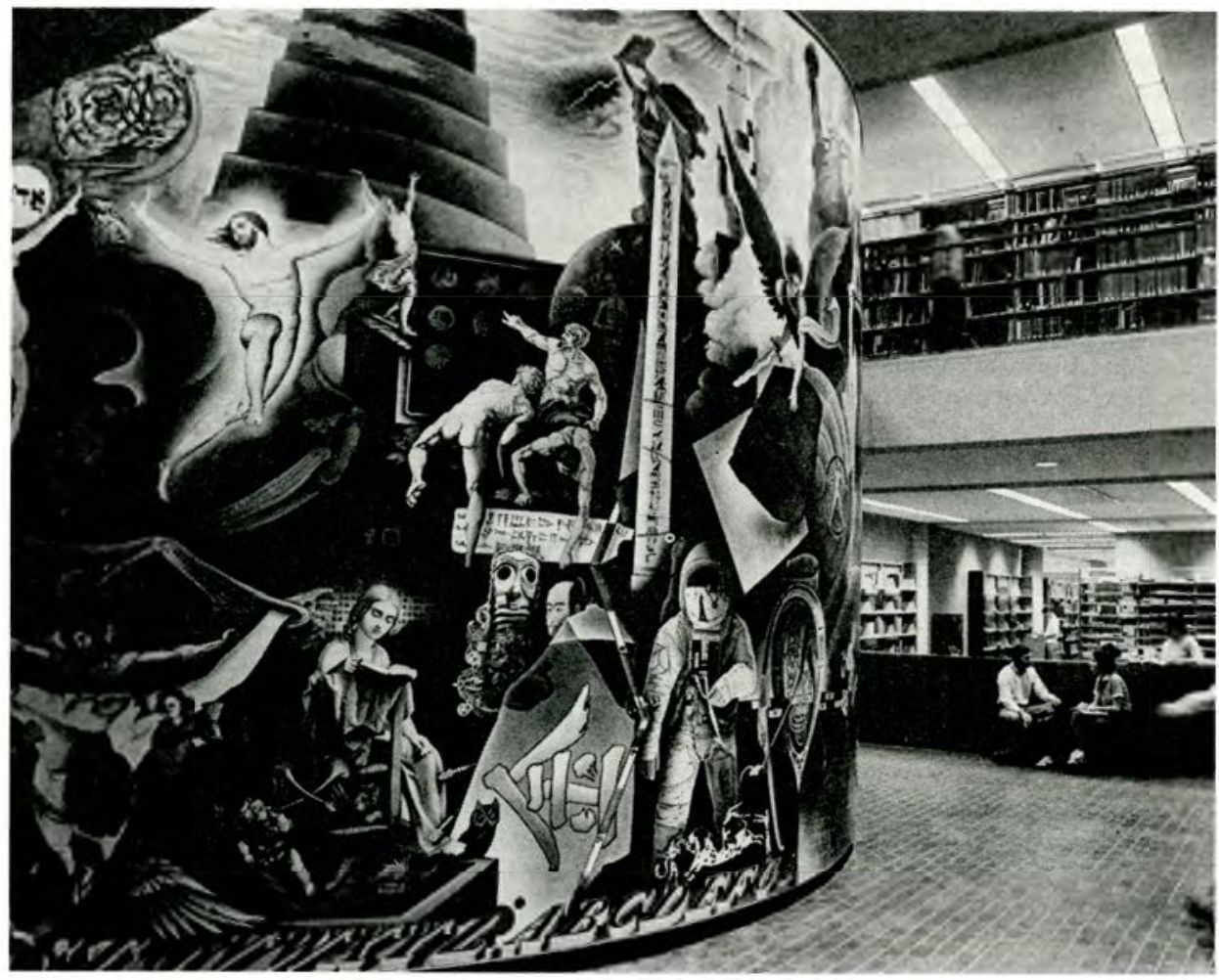

\section{Trinity University Library boasts the world's largest collage}

Trinity University's Maddux Library, San Antonio, was the subject of a write-up in the August 1984 Southern Living magazine. The circular wall around the library's central staircase features a panoramic $15^{\prime}$ x $80^{\prime}$ mural composed by Denverborn artist James Sicner, who has proclaimed it the largest collage in the world. More than 800 different historical and fictional drawings and illustrations cover the wall, including the Aztec calendar stone, the Magna Carta, Indian ceramics, the Rosetta stone, the Declaration of Independence, the Gutenberg Bible, an imprint of the first lunar footsteps, and characters from ancient alphabets. All the images are enlarged photographs of illustrations clipped from books, magazines, newspapers, and other printed material.

Appropriately (yet perhaps unfortunately for feminists and non-print specialists) titled "Man's Evolving Images-Printing and Writing," the mural required two years of research and 4 years of cutting, pasting, painting, and varnishing. Sicner was commissioned in 1977 by the Ewing Halsell
Foundation of San Antonio and finally completed the mural in the fall of 1983 in time for the library's dedication ceremony as the Elizabeth Coates Maddux Library.

Sicner used the following 12 steps in producing the mural: 1) selecting a print; 2) determining its final size; 3) enlarging and printing it on special archival paper; 4) cutting it out; 5) taping it to the wall for preliminary positioning; 6) trimming it; 7) wet-mounting; 8) drying; 9) varnishing; 10) shading; 11) glazing; and 12) revarnishing. The last two steps gave the mural a fantastic sensation of depth, space, and projection. The artist later painted in highlights, shadows, and shafts of light to blend the components together.

The actual cutting and pasting took place each evening after the library closed, to reduce distractions by inquisitive students and faculty. Sicner preferred doing his work to the accompaniment of tape recorded Gregorian chant or symphonic music. 